\title{
Metode Penilaian Walkability Permukiman di Perkotaan: Sebuah Kajian Literatur Sistematis
}

\author{
Alva F.P. Sondakh \\ Program Magister Arsitektur, SAPPK Institut Teknologi Bandung \\ alvasondakh2@yahoo.com
}

\begin{abstract}
ABSTRAK
Walkability permukiman memiliki beberapa peran penting dalam kehidupan kota. Tujuan pengkajian ini adalah untuk mengidentifikasi variabel-variabel yang dipakai dalam penilaian, mengidentifikasi metode pengambilan data, mengidentifikasi instrumen penelitian, dan mengidentifikasi metode analisis data yang dipakai oleh penelitian-penelitian terdahulu tentang Walkability permukiman. Kajian ini menggunakan metode kajian literatur sistematis terhadap 19 artikel tentang Walkability permukiman. Hasil analisis dan interpretasi menunjukkan bahwa kombinasi pengukuran kondisi faktual dan pendapat perseptual adalah hal yang bisa secara utuh menggambarkan nilai Walkability sebuah permukiman.
\end{abstract}

Kata kunci: metode penilaian, neighborhood walkability, akses dalam permukiman, kualitas hidup perkotaan.

\begin{abstract}
Neighborhood Walkability is an important factor in urban life. The purpose of this systematic review is to identify the variables used in the measurements, to identify the methods of data collection, to identify the research instruments, and to identify the methods of data analysis used by previous researchs on Neighborhood Walkability. This review used a systematic literature review method on 19 articles about Neighborhood Walkability. Results of analysis and interpretation has shown that a combination of measuring factual condition and perceptual opinion is best to describe the Neighborhood Walkability.
\end{abstract}

Keywords: assesment method, neighborhood walkability, neighborhood accessibility, urban quality of life.

\section{Pendahuluan}

Permukiman kota sebagai sebuah lingkungan binaan berhubungan erat dengan kualitas hidup perkotaan (Quality of Urban Life) penduduknya. Kualitas hidup perkotaan (QOUL), menurut Marans \& Stimson (2014), adalah kepuasan yang diterima seseorang dari kondisi lingkungan fisik dan sosial sekitarnya. Salah satu hal yang mempengaruhi QOUL itu adalah fasilitas (amenities) yang dimiliki oleh sebuah kawasan permukiman (Mulligan \& Carruthers, 2014:107). Ketersediaan dan kualitas yang baik dari fasilitas tersebut membawa pengaruh positif bagi kualitas hidup perkotaan penduduknya. Namun, ketersediaan dan kualitas menjadi tidak penting apabila tidak didukung oleh jaringan akses yang baik menuju fasilitas permukiman tersebut. Selain itu, pilihan cara mengakses atau moda transportasi juga memberi pengaruh pada kualitas hidup perkotaan penduduknya. Berbeda dengan transportasi bermotor, cara mengakses dengan berjalan kaki adalah satu hal yang memberi pengaruh positif terhadap kualitas hidup penduduk (Southworth, 2005).

Lingkungan terbangun yang memungkinkan orang untuk berjalan kaki dikenal dengan istilah walkable built environment. Menurut Southworth (2005:248), walkability tersebut terjadi jika sebuah lingkungan terbangun (atau permukiman) mendorong 
orang untuk berjalan kaki dengan menyediakan jalur pedestrian yang nyaman dan aman, lalu menghubungkan orang dengan tujuan perjalanannya dalam waktu dan usaha yang wajar, dan menyediakan pemandangan yang menarik di sepanjang perjalanannya tersebut. Walkability memiliki beberapa peran penting dalam kehidupan kota, antara lain: 1) sebagai dasar bagi sebuah kota berkelanjutan (sustainable); 2) sebagai pendorong terjadinya aktivitas sosial; 3) sebagai pendorong peningkatan kesehatan mental dan fisik.

Sejumlah kajian sistematis terdahulu telah meninjau dan memetakan penelitianpenelitian tentang penilaian walkability permukiman. Beberapa tinjauan mengkaji sejumlah besar penelitian, namun belum memasukkan penelitian-penelitian mutakhir (Moudon \& Lee, 2003; Brownson, et al., 2009), sedangkan kajian lainnya hanya terbatas pada sejumlah kecil metode penilaian (Kelly, et al., 2011; Manaugh \& El-Geneidy, 2011), atau terbatas pada alat nilai tertentu (Charreire, et al., 2014). Oleh karena itu, makalah ini selanjutnya akan mengisi celah pengetahuan dengan mengkaji penelitian-penelitian mutakhir (antara tahun 2005-2016) tentang penilaian walkability permukiman tanpa terbatas pada metode penilaian tertentu. Tujuan pengkajian ini adalah untuk mengidentifikasi variabel-variabel yang dipakai dalam penilaian, mengidentifikasi metode pengambilan data, mengidentifikasi instrumen penelitian, dan mengidentifikasi metode analisis data yang dipakai oleh penelitian-penelitian terdahulu tentang walkability permukiman. Hal ini dilakukan agar penelitian ini bisa bermanfaat dalam merumuskan sebuah panduan mutakhir dalam penilaian walkability permukiman.

\section{Metodologi}

Kajian ini menggunakan metode kajian literatur sistematis yang dikembangkan dari Ridley (2012:191), yang terurai dalam langkah-langkah berikut: 1) Pencarian literatur -terutama dari artikel jurnal-, dengan menggunakan kata kunci 'Neighborhood Walkability'; 2) Penyaringan literatur tahap pertama untuk memasukkan atau mengeluarkan artikel, menurut kriteria 'Neighborhood Walkability', 'Measure' dan variasinya, 'Assesment' dan variasinya, dalam bagian judul dan abstrak; 3) Penyaringan literatur tahap kedua setelah pembacaan kritis terhadap artikel terkait; 4) Ekstraksi data dari literatur menurut kriteria: variabel operasional, metode pengambilan data, instrumen penelitian; metode analisis data 5) Analisis dan sintesis data dengan menggunakan teknik coding dan metode klaster; 6) Interpretasi data dan kesimpulan.

\section{Hasil dan Analisis}

Pencarian literatur dilakukan menggunakan kata kunci: 'Neighborhood Walkability' melalui beberapa situs pencarian akademik, yaitu:

1. Scopus (https://www.scopus.com) pada tanggal 27 Maret 2017, menghasilkan 241 dokumen.

2. ScienceDirect (https://www.Sciencedirect.com) pada tanggal 27 Maret 2017, yang menghasilkan 399 dokumen.

Selain itu, pencarian juga dilakukan dengan menggunakan kata kunci: 'Neighborhood Walkability Assessment Tool' melalui situs Google Scholar (https://scholar.google.co.id) pada tanggal 27 Maret 2017, yang menghasilkan 1180 dokumen.

Dokumen yang ditemukan kemudian disaring dengan melihat keberadaan katakata kunci: "Neighborhood Walkability", "Measure" dan variasinya, "Assesment" dan variasinya, dalam bagian judul dan abstrak. Penyaringan tahap pertama tersebut menghasilkan 29 dokumen, yang kemudian disaring dalam penyaringan tahap kedua. 
Penyaringan tahap kedua dilakukan dengan memilih penerbitan antara tahun 20052016, dan dilanjutkan dengan pembacaan kritis untuk menemukan pembahasan tentang metode-metode pengukuran dan penilaian walkability yang dimaksud di awal. Penyaringan tahap kedua menghasilkan dokumen-dokumen seperti dalam tabel berikut, yang disusun berdasarkan kronologi penerbitan.

\section{Tabel 1. Dokumen hasil penyaringan tahap kedua}

\begin{tabular}{|c|c|c|c|}
\hline No & Author & No & Author \\
\hline 1 & $\begin{array}{l}\text { Frank, D.L., Schmid, T.L., Sallis, J.F., Chapman, } \\
\text { MS., \& Saelens, B.E. (2005) }\end{array}$ & 11 & $\begin{array}{l}\text { Van Dyck, D., Cardon, G., Deforche, B., Owen, N., Sallis, } \\
\text { J.F., \& De Bourdeaudhuij, I. (2010) }\end{array}$ \\
\hline 2 & $\begin{array}{l}\text { Leslie, E., Saelens, B.,Frank, L., Owen, N., } \\
\text { Bauman, A., Coffee, N., \& Hugo, G. (2005) }\end{array}$ & 12 & Weiss, R.L., Maantay, J.A., \& Fahs, M. (2010) \\
\hline 3 & Porta, S., \& Renne, J.L. (2005) & 13 & $\begin{array}{l}\text { Duncan, D.T., Aldstadt, J., Whalen, J., Melly, S.J., \& } \\
\text { Gortmaker, S.L. (2011) }\end{array}$ \\
\hline 4 & Kuzmyak, J.R., Baber, C, \& Savory, D. (2006) & 14 & Gebel, K., Bauman, K., Sugiyama, T., \& Owen, N. (2011) \\
\hline 5 & Scholssberg, M. (2006) & 15 & Lotfi, S., \& Koohsari, M.J. (2011) \\
\hline 6 & $\begin{array}{l}\text { Leslie, E., Coffee, N., Frank, L., Owen, N., } \\
\text { Bauman. A, \& Hugo, G. (2007) }\end{array}$ & 16 & $\begin{array}{l}\text { Van Dyck, D., Cardon, G.,Deforche, B., \& De } \\
\text { Bourdeaudhuij, I. (2011) }\end{array}$ \\
\hline 7 & $\begin{array}{l}\text { Moudon, A.V., Lee, C., Cheadle, A.D., Garvin, } \\
\text { C., Johnson, D.B., Schmid, T.L., \& Weathers, } \\
\text { R.D. (2007) }\end{array}$ & 17 & Azmi, D.I., Karim, H.A., \& Ahmad, P. (2013) \\
\hline 8 & $\begin{array}{l}\text { Frank, L.D., Sallis, J.F., Saelens, B.E., Leary, L., } \\
\text { Cain, K., Conway, T.L., \& Hess, P.M. (2010) }\end{array}$ & 18 & $\begin{array}{l}\text { Hajna, S., Dasgupta, K., Halparin, M., \& Ross, N.A., } \\
\text { (2013) }\end{array}$ \\
\hline 9 & $\begin{array}{l}\text { Carr, L.J., Dunsiger, S.I., \& Marcus, B.H. } \\
\text { (2010) }\end{array}$ & 19 & $\begin{array}{l}\text { Duncan, D.T., Aldstadt, J., Whalen, J., \& Melly, S.J. } \\
\text { (2013) }\end{array}$ \\
\hline 10 & Hoedl, S., Titze, S., \& Oja, P. (2010) & & \\
\hline
\end{tabular}

\section{Ekstraksi Data}

Hasil ekstraksi data dari artikel-artikel tersebut ditampilkan dalam tabel berikut:

Tabel 2. Hasil ekstraksi data

\begin{tabular}{|c|c|c|c|c|}
\hline No & $\begin{array}{c}\text { Variabel Penilaian } \\
\text { Neighborhood Walkability }\end{array}$ & $\begin{array}{l}\text { Metode } \\
\text { Pengambilan } \\
\text { Data }\end{array}$ & $\begin{array}{l}\text { Instrumen } \\
\text { Penelitian }\end{array}$ & $\begin{array}{c}\text { Metode } \\
\text { Analisis Data }\end{array}$ \\
\hline 1 & $\begin{array}{l}\text { Bentuk kota (Urban form) } \\
\text { - Kepadatan rumah } \\
\text { - Keterhubungan jalan (jumlah persimpangan) } \\
\text { - Keragaman guna-lahan }\end{array}$ & $\begin{array}{l}\text { Dokumen } \\
\text { (Peta) }\end{array}$ & $\begin{array}{l}\text { Peta Sistem } \\
\text { Informasi } \\
\text { Geografis } \\
\text { (GIS) }\end{array}$ & $\begin{array}{l}\text { - Studi Peta } \\
\text { (menurut } \\
\text { Moens, 2002) } \\
\text { - Analisis } \\
\text { deskriptif }\end{array}$ \\
\hline 2 & $\begin{array}{l}\text { Karakteristik Fisik Lingkungan (Faktual \& Perseptual): } \\
\text { - Kepadatan rumah } \\
\text { - Keragaman guna-lahan } \\
\text { - Kedekatan dan kemudahan akses ke keragaman guna-lahan } \\
\text { - Keterhubungan jalan (kepadatan persimpangan) } \\
\text { - Fasilitas jalan } \\
\text { - Estetika } \\
\text { - Keamanan lalu-lintas } \\
\text { - Keamanan dari kejahatan }\end{array}$ & $\begin{array}{l}\text { - Dokumen } \\
\text { (Peta) } \\
\text { - Survey }\end{array}$ & $\begin{array}{l}\text { - Peta GIS } \\
\text { - Kuesioner }\end{array}$ & $\begin{array}{l}\text { - Studi Peta } \\
\text { - Analisis } \\
\text { deskriptif }\end{array}$ \\
\hline
\end{tabular}




\begin{tabular}{|c|c|c|c|c|}
\hline 3 & $\begin{array}{l}\text { Indikator struktur kota (Urban fabric): } \\
\text { - Aksesibilitas } \\
\text { - Keragaman guna-lahan } \\
\text { - Area publik } \\
\text { - Pengamatan alami } \\
\text { - Keterhubungan jalan } \\
\text { - Jumlah bangunan dan kavling kosong } \\
\text { Indikator jalan (Street) } \\
\text { - Paparan langit } \\
\text { - Keterlanjutan fasad } \\
\text { - Ruang transparan dan transisi } \\
\text { - Lebar ruang sosial } \\
\text { - Kompleksitas visual } \\
\text { - Jumlah bangunan } \\
\text { - Ketersediaan tempat duduk } \\
\text { - Elemen pengganggu }\end{array}$ & $\begin{array}{l}\text { - Dokumen } \\
\text { (Peta) } \\
\text { - Dokumen } \\
\text { (Foto) }\end{array}$ & $\begin{array}{l}\text { - Peta GIS } \\
\text { - Kamera } \\
\text { Foto }\end{array}$ & $\begin{array}{l}\text { - Studi Peta } \\
\text { - Analisis } \\
\text { Visual (foto) } \\
\text { - Analisis } \\
\text { deskriptif }\end{array}$ \\
\hline 4 & $\begin{array}{l}\text { * Jarak bepergian dengan kendaraan (Vehicle Miles Traveled) } \\
\text { * Karakteristik sosioekonomi: } \\
\text { - Ukuran rumahtangga } \\
\text { - Jumlah anak } \\
\text { - Pendapatan } \\
\text { - Pemilikan kendaraan } \\
\text { - Jumlah pekerja } \\
\text { - Jumlah pengemudi } \\
\text { - Jenis rumah } \\
\text { - Suku bangsa } \\
\text { - Alur hidup } \\
\text { * Aksesibilitas kawasan } \\
\text { * Guna-lahan } \\
\text { - Kepadatan } \\
\text { - Keragaman } \\
\text { - Rancangan }\end{array}$ & $\begin{array}{l}\text { - Dokumen } \\
\text { (Peta) } \\
\text { - Dokumen } \\
\text { (Hasil sensus) } \\
\text { - Survey }\end{array}$ & $\begin{array}{l}\text { - Peta GIS } \\
\text { - Data } \\
\text { sensus } \\
\text { - Kuesioner }\end{array}$ & $\begin{array}{l}\text { - Analisis } \\
\text { deskriptif } \\
\text { - Analisis } \\
\text { Regresi }\end{array}$ \\
\hline 5 & $\begin{array}{l}\text { Kualitas - Klasifikasi jalan: } \\
\text { - Jalan kecil (panjang) } \\
\text { - Jalan utama (panjang) } \\
\text { - Kepadatan jumlah jalan kecil } \\
\text { - Rasio jalan kecil - jalan utama } \\
\text { Kedekatan - Area tangkapan pedestrian: } \\
\text { - Area tangkapan pedestrian } \\
\text { - Area tangkapan pedestrian yang terhalang } \\
\text { Keterhubungan - Persimpangan: } \\
\text { - Kepadatan persimpangan } \\
\text { - Kepadatan jalan buntu } \\
\text { - Rasio persimpangan - jalan buntu } \\
\text { - Kepadatan persimpangan yang terhalang } \\
\text { - Kepadatan jalan buntu yang terhalang } \\
\text { - Rasio persimpangan terhalang - jalan buntu terhalang } \\
\text { - Rasio perubahan persimpangan - jalan buntu }\end{array}$ & $\begin{array}{l}\text { Dokumen } \\
\text { (Peta) }\end{array}$ & Peta GIS & $\begin{array}{l}\text { - Studi Peta } \\
\text { - Analisis } \\
\text { Deskriptif }\end{array}$ \\
\hline 6 & $\begin{array}{l}\text { Data spasial: } \\
\text { - Kepadatan perumahan } \\
\text { - Keterhubungan jalan (kepadatan persimpangan) } \\
\text { - Guna-lahan } \\
\text { - Area ritel (net) }\end{array}$ & $\begin{array}{l}\text { Dokumen } \\
\text { (Peta) }\end{array}$ & Peta GIS & $\begin{array}{l}\text { - Studi Peta } \\
\text { - Analisis } \\
\text { Deskriptif }\end{array}$ \\
\hline 7 & $\begin{array}{l}\text { Model Perilaku Lingkungan: } \\
\text { - Tujuan Perjalanan (Fasilitas Permukiman) } \\
\text { - Jarak Perjalanan (menuju Tujuan) } \\
\text { - Rute Perjalanan } \\
\text { - Jenis dan Kepadatan perumahan }\end{array}$ & $\begin{array}{l}\text { Dokumen } \\
\text { (Peta) }\end{array}$ & Peta GIS & $\begin{array}{l}\text { - Studi Peta } \\
\text { - Analisis } \\
\text { Deskriptif }\end{array}$ \\
\hline
\end{tabular}




\begin{tabular}{|c|c|c|c|c|}
\hline 8 & $\begin{array}{l}\text { * Jarak Perjalanan dengan Kendaraan } \\
\text { * Pendapatan RT (Household Income) } \\
\text { * Komponen Walkability Index: } \\
\text { - Kepadatan perumahan } \\
\text { - Rasio luas lantai bangunan ritel } \\
\text { - Kepadatan persimpangan (Keterhubungan jaringan jalan) } \\
\text { - Keragaman guna-lahan }\end{array}$ & $\begin{array}{l}\text { - Dokumen } \\
\text { (Peta) } \\
\text { - Dokumen } \\
\text { (Hasil sensus) } \\
\text { - Observasi }\end{array}$ & $\begin{array}{l}\text { - Peta GIS } \\
\text { - Data } \\
\text { sensus }\end{array}$ & $\begin{array}{l}\text { - Studi Peta } \\
\text { - Analisis } \\
\text { Deskriptif } \\
\text { - Analisis } \\
\text { Visual } \\
\text { - Analisis } \\
\text { Regresi }\end{array}$ \\
\hline 9 & $\begin{array}{l}\text { * Keterhubungan jalan } \\
\text { - Kepadatan persimpangan } \\
\text { - Kepadatan jalan (dalam panjang) } \\
\text { - Rata-rata panjang blok } \\
\text { * Kepadatan perumahan } \\
\text { * Jumlah pos perhentian bis } \\
\text { * Jumlah kejahatan } \\
\text { * Lingkungan (perseptual) } \\
\text { - Akses ke fasilitas aktivitas fisik (perseptual) } \\
\text { - Lingkungan aktivitas fisik (perseptual) }\end{array}$ & $\begin{array}{l}\text { - Dokumen } \\
\text { (Peta) } \\
\text { - Dokumen } \\
\text { (Hasil sensus) } \\
\text { - Survey }\end{array}$ & $\begin{array}{l}\text { - Peta GIS } \\
\text { - Data } \\
\text { Sensus } \\
\text { - Kuesioner }\end{array}$ & $\begin{array}{l}\text { - Studi Peta } \\
\text { - Analisis } \\
\text { Deskriptif } \\
\text { - Analisis } \\
\text { Korelasi }\end{array}$ \\
\hline 10 & $\begin{array}{l}\text { * Daya tarik lingkungan sekitar } \\
\text { - Papan reklame } \\
\text { - Baris penghijauan } \\
\text { - Pohon } \\
\text { - Area penghijauan } \\
\text { - Taman bermain } \\
\text { - Taman terbuka } \\
\text { * Guna-lahan } \\
\text { - Perumahan } \\
\text { - Bisnis } \\
\text { - Bangunan khusus } \\
\text { * Infrastruktur pejalan kaki }\end{array}$ & Observasi & $\begin{array}{l}\text { Checklist } \\
\text { observasi }\end{array}$ & $\begin{array}{l}\text { Analisis } \\
\text { deskriptif }\end{array}$ \\
\hline 11 & $\begin{array}{l}\text { Neighborhood Walkability Index: } \\
\text { - Kepadatan perumahan } \\
\text { - Kepadatan persimpangan (keterhubungan) } \\
\text { - Keragaman guna-lahan }\end{array}$ & $\begin{array}{l}\text { Dokumen } \\
\text { (Peta) }\end{array}$ & Peta GIS & $\begin{array}{l}\text { - Studi Peta } \\
\text { - Analisis } \\
\text { deskriptif }\end{array}$ \\
\hline 12 & $\begin{array}{l}\text { - Keragaman guna-lahan (faktual \& perseptual) } \\
\text { - Keterhubungan jalan \& perawatannya (faktual \& } \\
\text { perseptual) } \\
\text { - Estetika Neighborhood (faktual \& perseptual) } \\
\text { - Keamanan pedestrian (faktual \& perseptual) } \\
\text { - Keamanan Neighborhood (faktual \& perseptual) }\end{array}$ & $\begin{array}{l}\text { - Dokumen } \\
\text { (Peta) } \\
\text { - Observasi } \\
\text { - Survey }\end{array}$ & $\begin{array}{l}\text { - Peta GIS } \\
\text { - PDA dan } \\
\text { software } \\
\text { observasi } \\
\text { - Kuesioner }\end{array}$ & $\begin{array}{l}\text { - Studi Peta } \\
\text { - Analisis } \\
\text { deskriptif }\end{array}$ \\
\hline 13 & $\begin{array}{l}\text { Objective neighborhood walkability indicators: } \\
\text { - Jumlah tujuan berjalan (Ritel) } \\
\text { - Jumlah tujuan berjalan (Jasa) } \\
\text { - Jumlah tujuan berjalan (Budaya/Pendidikan) } \\
\text { - Jumlah taman } \\
\text { - Kelangsungan (Directness) rute pedestrian } \\
\text { - Kepadatan persimpangan } \\
\text { - Jumlah kuldesak } \\
\text { - Batas kecepatan rata-rata } \\
\text { - Kepadatan jalan raya (highway) } \\
\text { - Kepadatan perumahan } \\
\text { - Kepadatan penduduk }\end{array}$ & $\begin{array}{l}\text { Dokumen } \\
\text { (Peta) }\end{array}$ & Peta GIS & $\begin{array}{l}\text { - Studi Peta } \\
\text { - Analisis } \\
\text { deskriptif }\end{array}$ \\
\hline 14 & $\begin{array}{l}\text { Atribut Lingkungan (Faktual \& Perseptual): } \\
\text { - Kepadatan hunian } \\
\text { - Keterhubungan jalan } \\
\text { - Keragaman guna-lahan } \\
\text { - Rasio net luas bangunan ritel }\end{array}$ & $\begin{array}{l}\text { - Dokumen } \\
\text { (Peta) } \\
\text { - Survey }\end{array}$ & $\begin{array}{l}\text { - Peta GIS } \\
\text { - Kuesioner }\end{array}$ & $\begin{array}{l}\text { - Studi Peta } \\
\text { - Analisis } \\
\text { deskriptif }\end{array}$ \\
\hline 15 & $\begin{array}{l}\text { Ukuran obyektif lingkungan terbangun: } \\
\text { - Kepadatan perumahan }\end{array}$ & $\begin{array}{l}\text { - Dokumen } \\
\text { (Hasil sensus) }\end{array}$ & $\begin{array}{l}\text { - Data } \\
\text { sensus }\end{array}$ & $\begin{array}{l}\text { - Analisis } \\
\text { deskriptif }\end{array}$ \\
\hline
\end{tabular}




\begin{tabular}{|c|c|c|c|c|}
\hline & $\begin{array}{l}\text { - Keragaman guna-lahan } \\
\text { - Kepadatan persimpangan } \\
\text { - Area parkir } \\
\text { Ukuran kerentanan sosial: } \\
\text { - Jumlah populasi } \\
\text { - Kualitas Housing } \\
\text { - Status sosioekonomi }\end{array}$ & $\begin{array}{l}\text { - Dokumen } \\
\text { (Database) } \\
\text { - Survey } \\
\text { (Wawancara) }\end{array}$ & $\begin{array}{l}\text { - Daftar } \\
\text { pertanyaan } \\
\text { wawancara }\end{array}$ & \\
\hline 16 & $\begin{array}{l}\text { Karakteristik walkability: } \\
\text { - Kepadatan perumahan } \\
\text { - Keragaman guna-lahan } \\
\text { - Keterhubungan jalan }\end{array}$ & $\begin{array}{l}\text { - Dokumen } \\
\text { (Peta) }\end{array}$ & - Peta GIS & $\begin{array}{l}\text { - Analisis } \\
\text { deskriptif }\end{array}$ \\
\hline 17 & Persepsi aksesibilitas (lama perjalanan) & Survey & Kuesioner & $\begin{array}{l}\text { Analisis } \\
\text { deskriptif }\end{array}$ \\
\hline 18 & 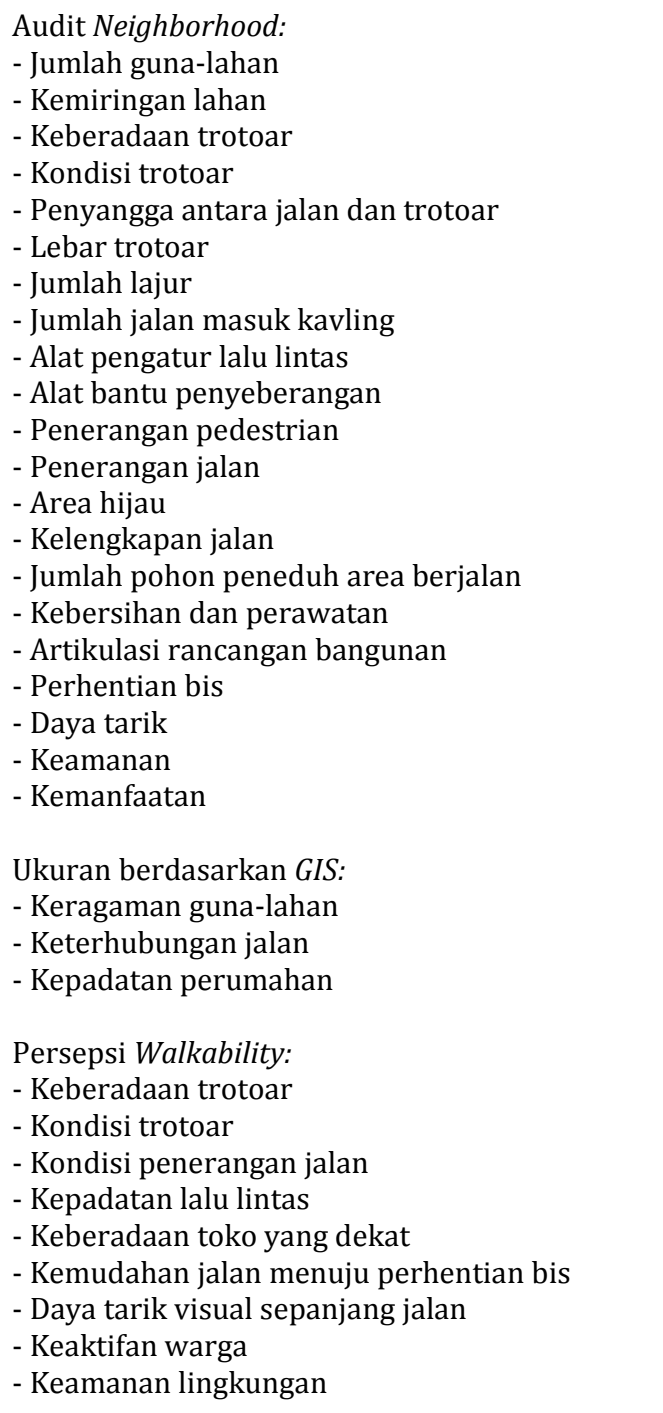 & $\begin{array}{l}\text { - Observasi } \\
\text { - Dokumen } \\
\text { (Peta) } \\
\text { - Survey }\end{array}$ & $\begin{array}{l}\text { - Checklist } \\
\text { observasi } \\
\text { - Peta GIS } \\
\text { - Kuesioner }\end{array}$ & $\begin{array}{l}\text { - Studi Peta } \\
\text { - Analisis } \\
\text { Deskriptif }\end{array}$ \\
\hline 19 & $\begin{array}{l}\text { - Jumlah tujuan berjalan (Ritel) } \\
\text { - Jumlah tujuan berjalan (Jasa) } \\
\text { - Jumlah tujuan berjalan (Budaya \& Pendidikan) } \\
\text { - Jumlah area rekreasi terbuka } \\
\text { - Jumlah taman } \\
\text { - Jumlah perhentian bis } \\
\text { - Jumlah perhentian bawah tanah } \\
\text { - Kelangsungan (Directness) rute pedestrian } \\
\text { - Kepadatan persimpangan }\end{array}$ & $\begin{array}{l}\text { - Dokumen } \\
\text { (Peta) } \\
\text { - Dokumen } \\
\text { (Hasil Sensus) }\end{array}$ & $\begin{array}{l}\text { - Peta GIS } \\
\text { - Data } \\
\text { Sensus }\end{array}$ & $\begin{array}{l}\text { - Studi Peta } \\
\text { - Analisis } \\
\text { deskriptif }\end{array}$ \\
\hline
\end{tabular}


- Keberadaan trotoar

- Lebar rata-rata trotoar

- Batas rata-rata kecepatan

- Kepadatan jalan raya

- Kepadatan perumahan

- Kepadatan penduduk

\section{Analisis Data}

Data-data yang diekstraksi tersebut selanjutnya dianalisis dan dikelompokkan dalam beberapa kelompok kategori, yaitu: 1) Kategori variabel operasional; 2) Kategori metode pengambilan data; 3) Kategori instrumen pengambilan data; dan 4) Kategori metode analisis data. Data-data variabel operasional dikelompokkan menurut kesamaan substansi variabel sehingga jumlah total variabel telah berkurang, dan penamaan beberapa variabel telah mengalami perubahan. Kelompok kategori tersebut ditampilkan dalam beberapa tabel berikut.

Tabel 3a. Kelompok kategori variabel operasional (faktual)

\begin{tabular}{|c|c|}
\hline Kategori & Variabel \\
\hline Kondisi Sosioekonomi Warga & $\begin{array}{ll}\text { - } & \text { Kepadatan penduduk } \\
\text { - } & \text { Pekerjaan } \\
\text { - } & \text { Pendapatan } \\
\text { - } & \text { Ukuran rumah tangga } \\
\text { - } & \text { Pemilikan kendaraan } \\
\text { - } & \text { Suku bangsa }\end{array}$ \\
\hline Guna Lahan & $\begin{array}{l}\text { - Keragaman guna-lahan } \\
\text { O Area Perumahan } \\
\\
\text { - J Kepadatan hunian } \\
\text { Area Ritel Kualitas rumah } \\
\square \quad \text { Luas lantai bangunan ritel } \\
\circ \quad \text { Bangunan khusus } \\
\circ \quad \text { Kavling kosong } \\
\text { - Kepadatan guna-lahan }\end{array}$ \\
\hline Konektivitas & $\begin{array}{ll}\text { - Konektivitas jalan } \\
\circ & \text { Jumlah jalan utama } \\
\circ & \text { Jumlah jalan kecil } \\
\circ & \text { Kepadatan (Density) jalan } \\
\circ & \text { Kepadatan persimpangan } \\
\circ & \text { Rasio jalan kecil - jalan utama } \\
\circ & \text { Rute perjalanan } \\
\circ & \text { Jarak perjalanan dengan kendaraan } \\
\text { - Konektivitas pedestrian } \\
\quad \text { Kelangsungan (directness) rute pedestrian }\end{array}$ \\
\hline Infrastruktur & $\begin{array}{cl}\text { - Infrastruktur jalan } \\
\circ & \text { Fasilitas jalan } \\
\circ & \text { Kelengkapan jalan } \\
\circ & \text { Lajur kendaraan } \\
\circ & \text { Kuldesak } \\
\circ & \text { Alat bantu penyeberangan } \\
\circ & \text { Alat pengatur lalu-lintas } \\
\circ & \text { Keamanan lalu-lintas } \\
\circ & \text { Batas rata-rata kecepatan } \\
\circ & \text { Penerangan Jalan }\end{array}$ \\
\hline
\end{tabular}


- Infrastruktur pedestrian

$\begin{array}{ll}\circ & \text { Keberadaan trotoar } \\ \circ & \text { Kondisi trotoar } \\ \circ & \text { Lebar trotoar } \\ \circ & \text { Kebersihan dan perawatan } \\ \circ & \text { Jalan masuk kavling } \\ \circ & \text { Lebar ruang sosial } \\ \circ & \text { Area penyangga antara jalan dan trotoar } \\ \circ & \text { Pengamatan alami } \\ \circ & \text { Penerangan pedestrian } \\ \circ & \text { Keamanan pedestrian } \\ \circ & \text { Ketersediaan tempat duduk }\end{array}$

\begin{tabular}{lll}
\hline Destinasi perjalanan & $\bullet$ & Fasilitas Jasa \\
& $\bullet$ & Fasilitas Ritel \\
& $\bullet$ & Fasilitas Budaya \& Pendidikan \\
& $\bullet$ & Fasilitas Rekreasi (Taman, Area terbuka) \\
& $\bullet$ & Pos perhentian sarana transportasi (bis, kereta, dll) \\
\hline Estetika Lingkungan & $\bullet$ & Baris penghijauan \\
& $\bullet$ & Kompleksitas visual \\
& $\bullet$ Keterlanjutan fasad \\
& $\bullet$ Pohon peneduh \\
& $\bullet$ Paparan langit \\
\hline Lain-lain & $\bullet$ Keamanan Lingkungan \\
& $\bullet$ Kondisi topografi lingkungan \\
\hline
\end{tabular}

Tabel 3b. Kelompok kategori variabel operasional (perseptual)

\begin{tabular}{|c|c|}
\hline Kategori & Variabel \\
\hline Konektivitas & $\begin{array}{l}\text { - Konektivitas jalan } \\
\text { - Lama perjalanan } \\
\text { - Konektivitas pedestrian } \\
\circ \quad \text { Kedekatan ke keragaman guna-lahan } \\
\circ \quad \text { Kemudahan akses ke keragaman guna-lahan } \\
\circ \quad \text { Kelangsungan (directness) rute pedestrian }\end{array}$ \\
\hline Infrastruktur & $\begin{aligned} & \text { - Infrastruktur jalan } \\
& \circ \text { Fasilitas jalan } \\
& \circ \text { Kelengkapan jalan } \\
& \circ \text { Keamanan lalu-lintas } \\
& \circ \text { Penerangan Jalan } \\
& \text { - } \quad \text { Infrastruktur pedestrian } \\
& \circ \text { Keberadaan trotoar } \\
& \circ \text { Kondisi trotoar } \\
& \circ \text { Lebar trotoar } \\
& \circ \text { Kebersihan dan perawatan } \\
& \circ \text { Lebar ruang sosial } \\
& \circ \text { Area penyangga antara jalan dan trotoar } \\
& \circ \text { Pengamatan alami } \\
& \circ \text { Penerangan pedestrian } \\
& \circ \text { Keamanan pedestrian }\end{aligned}$ \\
\hline Destinasi perjalanan & $\begin{array}{l}\text { - } \quad \text { Fasilitas Jasa } \\
\text { - } \quad \text { Fasilitas Ritel } \\
\text { - } \quad \text { Fasilitas Budaya \& Pendidikan } \\
\text { - } \quad \text { Fasilitas Rekreasi (Taman, Area terbuka) } \\
\text { - } \quad \text { Pos perhentian sarana transportasi (bis, kereta, dll) }\end{array}$ \\
\hline
\end{tabular}




\begin{tabular}{ll}
\hline Estetika Lingkungan & $\bullet$ Baris penghijauan \\
& $\bullet$ Kompleksitas visual \\
& $\bullet$ Pohon peneduh \\
\hline Lain-lain & $\bullet$ Keamanan Lingkungan \\
& $\bullet$ Kondisi topografi lingkungan \\
\hline
\end{tabular}

Metode pengambilan data yang digunakan dalam artikel-artikel tersebut adalah:

- Dokumen (Peta): 16 artikel

- Survey (Kuesioner): 7 artikel

- Dokumen (Hasil sensus): 5 artikel

- Observasi: 4 artikel

- Survey (Wawancara): 1 artikel

- Dokumen (Database): 1 artikel

- Dokumen (Foto): 1 artikel adalah:

Instrumen pengambilan data yang digunakan dalam artikel-artikel tersebut

- Peta GIS: 16 artikel

- Kuesioner: 7 artikel

- Data sensus: 5 artikel

- Checklist observasi: 2 artikel

- Daftar pertanyaan wawancara: 1 artikel

- Kamera Foto: 1 artikel

- PDA dan software observasi: 1 artikel

Metode analisis data yang digunakan dalam artikel-artikel tersebut adalah:

- Analisis Deskriptif: 19 artikel

- Studi Peta: 14 artikel

- Analisis Regresi: 2 artikel

- Analisis Korelasi: 1 artikel

- Analisis Visual: 1 artikel

- Analisis Visual (foto): 1 artikel

\section{Interpretasi Data dan Diskusi}

Data-data di atas menunjukkan bahwa Dokumen (Peta) dan Survey (Kuesioner) merupakan metode pengambilan data yang paling banyak dilakukan. Instrumen penelitian yang paling banyak digunakan adalah Peta GIS dan Kuesioner. Sedangkan metode analisis data yang paling banyak digunakan adalah analisis Deskriptif dan Studi Peta. Hal tersebut menunjukkan bahwa pengukuran walkability permukiman bisa dilakukan dengan melihat kondisi faktual (melalui Analisis Peta GIS) maupun lewat persepsi individu (melalui kuesioner).

Secara faktual, Duncan, et al. (2013) menunjukkan bahwa peta GIS bisa menampung sejumlah besar variabel fisik lingkungan permukiman, yang menambah tingkat akurasi penilaian walkability permukiman tersebut. Di sisi lain, persepsi individu terhadap walkability sebuah permukiman bisa secara akurat didapatkan melalui kuesioner, seperti yang ditunjukkan oleh Azmi, et al. (2013). Namun demikian, kombinasi dari pengukuran kondisi faktual dan pendapat perseptual adalah hal yang bisa secara utuh menggambarkan nilai walkability sebuah permukiman. 


\section{Kesimpulan}

Walkability permukiman adalah salah satu aspek penting dalam kehidupan perkotaan, yang bisa dinilai secara utuh lewat kombinasi pengukuran faktual dan pengukuran perseptual. Hasil kajian sistematis ini telah menunjukkan variabel operasional, metode dan instrumen pengambilan data, serta metode analisis data yang bisa digunakan dalam penilaian walkability tersebut.

Keterbatasan penelitian ini terletak pada kurangnya jumlah artikel yang dikaji. Pengembangan kajian selanjutnya bisa dilakukan dengan memperluas pencarian artikel memakai mesin pencari akademik yang lebih banyak. Pengembangan kajian selanjutnya juga bisa dilakukan dengan menambah aspek-aspek yang diidentifikasi dari artikelartikel tersebut.

\section{DAFTAR PUSTAKA}

Azmi, D.I., \& Karim, H.A., \& Ahmad, P. (2013). Comparative study of neighbourhood walkability to community facilites between two precincts in Putrajaya. Procedia Social and Behavioral Sciences, 105, 513-524.

Brownson, R.C., Hoehner, C.M., Day, K., Forsyth, A., \& Sallis, J.F. (2009). Measuring the built environment for physical activity: State of the science. American Journal of Preventive Medicine, 36(4S): S99-S123.

Carr, L.J., Dunsiger, S.I., \& Marcus, B.H. (2010). Walk Score as a global estimate of neighborhood walkability. American Journal of Preventive Medicine, 39(5): 460463.

Charreire, H., Mackenbach, J.D., Ouasti, M., Lakerveld, J., Compernolle, S., Ben-Rebah, M., McKee, M., Brug, J., Rutter, H., \& Oppert, J.-M. (2014). Using remote sensing to define environmental characteristics related to physical activity and dietary behaviours: A systematic review (the SPOTLIGHT project). Health \& Place, 25: 19.

Duncan, D.T., Aldstadt, J., Whalen, J., Melly, S.J., \& Gortmaker, S.L. (2011). Validation of Walk Score for estimating neighborhood walkability: An analysis of four US metropolitan areas. International Journal of Environmental Research and Public Health, 8: 4160-4179.

Frank, D.L., Schmid, T.L., Sallis, J.F., Chapman, MS., \& Saelens, B.E. (2005). Linking objectively measured physical activity with objectively measured urban form: Findings from SMARTRAQ. American Journal of Preventive Medicine, 28 (2S2), 117-125.

Frank, L.D., Sallis, J.F., Saelens, B.E., Leary, L., Cain, K., Conway, T.L., \& Hess, P.M. (2010). The development of a walkability index: Application to the Neighborhood Quality of Life Study. British Journal of Sports Medicine, 44: 924-933

Gebel, K., Bauman, K., Sugiyama, T., \& Owen, N. (2011). Mismatch between perceived and objectively assessed neighborhood walkability attributes: Prospective relationships with walking and weight gain. Health \& Place, 17: 519-524.

Hajna, S., Dasgupta, K., Halparin, M., \& Ross, N.A., (2013). Neighborhood walkability: Field validation of geographic information system measures. American Journal of Preventive Medicine. 44(6): e55-e59.

Hoedl, S., Titze, S., \& Oja, P. (2010). The bikeability and walkability evaluation table. American Journal of Preventive Medicine, 39(5): 457-459

Kelly, C.E., Tight, M.R., Hodgson, F.C., \& Page, M.W. (2011). A comparison of three methods for assessing the walkability of the pedestrian environment. Journal of 
Transport Geography, 19: 1500-1508.

Kuzmyak, J.R., Baber, C, \& Savory, D. (2006). Use of walk opportunities index to quantify local accessibility. Transportation Research Record: Journal of the Transportation Research Board, No. 1977, 145-153.

Leslie, E., Saelens, B., Frank, L., Owen, N., Bauman, A., Coffee, N., \& Hugo, G. (2005). Residents' perceptions of walkability attributes in obejectively different neighbourhoods: A pilot study. Health \& Place, 11: 227-236.

Leslie, E., Coffee, N., Frank, L., Owen, N., Bauman. A., \& Hugo, G. (2007). Walkability of local communities: Using geographic information systems to objectively assess relevant environmental attributes. Health \& Place, 13: 111-122

Lotfi, S., \& Koohsari, M.J. (2011). Neighborhood walkability in a city within a developing country. Journal of Urban Planning and Development, 137(4): 402-408.

Manaugh, K., \& El-Geneidy, A. (2011). Validating walkability indices: How do different households respond to the walkabilty of their neighborhood?. Transportation Research Part D, 16, 309-315.

Marans, R. W., \& Stimson, R. J. (2014). An overview of quality of urban life. Dalam R.W. Marans, \& R.J. Stimson (Eds.). Investigating quality of urban life: theory, methods, and empirical research. (pp. 1-29). Dordrecht: Springer.

McCrea, R., Stimson, R., \& Marans, R.W. (2014). The evolution of integrative approaches to the analysis of quality of urban life. Dalam R.W. Marans, \& R.J. Stimson (Eds.). Investigating quality of urban life: theory, methods, and empirical research. (pp. 77-104). Dordrecht: Springer.

Moens, R. (2002). Map study. Dalam T.M. de Jong \& D.J.M. van de Voordt (Eds.). Way6s to study and research urban, architectural and technical design. Delft, The Netherlands: DUP Science.

Moudon, A.V., \& Lee, C. (2003). Walking and bycycling: An evaluation of environmental audit instruments. American Journal of Health Promotion, 18(1): 21-37.

Moudon, A.V., Lee, C., Cheadle, A.D., Garvin, C., Johnson, D.B., Schmid, T.L., \& Weathers, R.D. (2007). Attributes of environment supporting walking. American Journal of Health Promotion, 21(5): 448-459.

Mulligan, G.F., \& Carruther, J.I. (2014). Amenities, quality of life, and regional development. Dalam R.W. Marans, \& R.J. Stimson (Eds.). Investigating quality of urban life: theory, methods, and empirical research. (pp. 107-133). Dordrecht: Springer.

Porta, S., \& Renne, J.L. (2005) Linking urban design to sustainability: Formal indicators of social urban sustainability field research in Perth, Western Australia. Urban Design International, 10: 51-64

Ridley, D. (2012). The literature review: A step-by-step guide for students. London, UK: SAGE Publications Ltd.

Scholssberg, M. (2006). From TIGER to audit instruments: Measuring neighborhood walkability with street data based on geographic information systems. Transportation Research Record: Journal of the Transportation Research Board, No. 1982, 47-56.

Schlossberg, M., Agrawal, A.W., \& Irvin, K. (2007). An assessment of GIS-enabled walkability audits. URISA Journal, 19(2)

Southworth, M. (2005). Designing the walkable city. Journal of Urban Planning and Development, 131(4), 246-257.

Van Dyck, D., Cardon, G., Deforche, B., Owen, N., Sallis, J.F., \& De Bourdeaudhuij, I. (2010). Neighborhood Walkability and Sedentary Time in Belgian Adults. American Journal of Preventive Medicine, 39(1): 25-32. 
Van Dyck, D., Cardon, G., Deforche, B., \& De Bourdeaudhuij, I. (2011). Do adults like living in high-walkable neighborhoods? Associations of walkability parameters with neighborhood satisfaction and possible mediators. Health \& Place, 17: 971-977.

Weiss, R.L., Maantay, J.A., \& Fahs, M. (2010). Promoting active urban aging: A measurement approach to neighborhood walkability for older adults. Cities and the Environment, 3(1):12. 